\title{
Exercise training in cancer related cardiomyopathy
}

\author{
Julian G. Westphal, P. Christian Schulze \\ Department of Internal Medicine I, Division of Cardiology, Pneumology, Angiology and Intensive Medical Care, University Hospital Jena, \\ Friedrich-Schiller-University Jena, Jena, Germany \\ Contributions: (I) Conception and design: All authors; (II) Administrative support: All authors; (III) Provision of study materials or patients: None; \\ (IV) Collection and assembly of data: All authors; (V) Data analysis and interpretation: All authors; (VI) Manuscript writing: All authors; (VII) Final \\ approval of manuscript: All authors. \\ Correspondence to: Dr. Julian Georg Westphal. Department of Internal Medicine I, University Hospital Jena, Am Klinikum I, 07747 Jena, Germany. \\ Email: Julian.westphal@med.uni-jena.de.
}

\begin{abstract}
The therapeutic options for malignancies have been expanding over the past decades. Since the rise of targeted therapies, improved survival rates and decreased morbidity of cancer patients are evident but these refined protocols have steadily increased the number of patients at risk for long-term side-effects of anti-neoplastic treatments. The leading causes of death in cancer survivors are now defined by cardiovascular disease. Thus, there is a growing need for understanding how cancer related cardiovascular diseases such as cardiomyopathies or vasculopathies develop and how this can be prevented. Besides classical symptoms of heart failure with or without decompensation, an overwhelming majority of cancer patients develop fatigue and a significant reduction in exercise capacity when compared to their pre-cancer state. These effects seem to be independent from the specific chemotherapeutic substance included in the treatment regimen. Recent trials have suggested beneficial effects of exercise regiments in early and late phases of cancer treatment regimens and during rehabilitation. This review focuses on the currently available literature and evidence for the role of exercise training in preventing declining cardiac function or improving an already impaired function during or after chemotherapy, radiation or other cancer-specific therapies.
\end{abstract}

Keywords: Cardiomyopathy; cancer; exercise; chemotherapy; heart failure

Submitted Nov 21, 2018. Accepted for publication Dec 10, 2018.

doi: $10.21037 /$ jtd.2018.12.53

View this article at: http://dx.doi.org/10.21037/jtd.2018.12.53

\section{Introduction}

The development of new medical therapies in oncology over the past decades is an impressive success and has fundamentally changed the outcome of cancer patients. Improved diagnostic algorithms and an increasing arsenal of modern and novel therapies allowed achieving higher rates of remission and cancer-free survival for many malignancies. As a result, a significant improvement in survival rates is evident and the medical community is confronted with a larger number of patients who have a history of oncological treatment and are at risk for related cardiac complications (1). If expressed in numbers, one can see an increase in the overall 5 -year survival rates for all cancers in the United States that rose from around $50 \%$ in the late seventies to
$69 \%$ in the past decade (1).

However, this apparent success is accompanied by a growing number of cancer survivors who face the consequences of the chemotherapeutic regimens and novel therapies with a wide range of unintended side effects. One of the biggest issues due to its mortality-defining nature is the wide range of cardiac and cardiovascular toxicities affecting the entire cardiovascular-skeletal muscle axis $(2,3)$. This affects not only patients currently in treatment but also patients with preexisting cardiovascular conditions going into therapy. This is considerably noteworthy because many forms of cancer share almost all risk factors with cardiovascular diseases (4). For example, a recent community-based study showed an inverse relation between cancer incidence and the absence of seven predefined 
cardiovascular risk factors as defined by the AHA (5). One of the worst complications of chemotherapeutic treatments is the development of chemotherapy-related cardiomyopathy (CRC) which can develop years if not decades following the initial treatment. The mortality rate in cancer survivors with cardiomyopathies is significantly higher than for idiopathic non-ischemic cardiomyopathy. A study in 2000 found a 3.5 -fold increase in mortality for doxorubicin induced cardiomyopathy compared to idiopathic non-ischemic cardiomyopathy. The significance of the issue was highlighted in a cohort study published in 2011 that showed that the leading cause of mortality for breast-cancer survivors was cardiovascular even surpassing the relapsing underlying malignant condition (6).

To address the need of adequate screening, prevention and treatment of CRC the term "cardio-oncology" has been coined as preventing heart failure in patients paramount for their long-term health not only because of the increased cardiovascular mortality but also because worsening cardiac function may limit their possibility to receive adequate cancer treatment $(7,8)$. Unsurprisingly, the involvement of a cardiologist in most stages of cancer treatment in terms of a multidisciplinary approach is recommended more and more frequently in current guidelines (9). Moreover an overwhelming amount of cancer survivors suffer from a reduction in quality-of-life related to symptoms of fatigue, nausea, pain and depression occur frequently. Studies also show that exercise capacity as measured in cardiopulmonary exercise testing is reduced in approximately $70 \%$ of cancer patients (10).

This review focuses on the currently available evidence for the role of exercise training in preventing declining cardiac function or improving an already impaired function during or after chemotherapy, radiation or other cancerspecific therapies.

\section{Cancer-related cardiomyopathy}

Cancer-related cardiomyopathy (CRC) is a condition with very heterogeneous underlying pathomechanisms due to the varying modes of action of the suspected causing drug (11). Ewer and Lippman introduced a general classification in 2005 which is based on the presence or absence of structural abnormalities and the extent of functional reversibility. Subsequently CRC is classified in an injury type with permanent loss of function (Type 1) and a dysfunction type with temporarily and often reversible loss of cardiac function (Type 2) (12). Even though this classification seems appealing recent MRI studies showing scar formations in Type 2 patients and improving cardiac function with guideline directed medical therapy (GDMT) in presumed Type 1 patients have called the validity of the classification into question $(13,14)$. A more recent attempt at defining CRC suggested the diagnostic criteria as a decrease in left ventricular ejection fraction (LVEF) by $5 \%$ or more to less than $55 \%$ in the presence of symptoms of heart failure or an asymptomatic decrease in LVEF by $10 \%$ or more to less than $55 \%(15)$.

The list of drugs suspected or proven to cause CRC is long and probably growing with the continuing introduction of modern novel therapy protocols. One of the best studied and well-established drugs classes are probably anthracyclines usually causing permanent structural changes. Also anthracycline induced CRC is occurring quite frequently and is usually associated with a poor prognosis $(16,17)$. Among other substance classes that can cause structural cardiac impairment are highdose alkylating agents and small-molecule tyrosine kinase inhibitors (18). The class of monoclonal antibody-based tyrosine kinase inhibitors most famously trastuzumab can be described as the "prototype substance" for Type 2 CRC, as the impaired cardiac function usually improves with discontinuation of the therapy. Interestingly the incidence of CRC in patients treated with trastuzumab is higher when concurrently treated with anthracyclines (19). The recent addition of checkpoint inhibitors targeting CTLA-4 (ipilimumab), PD-1 (nivolumab and pembrolizumab) and PD-L1 (atezolizumab, durvalumab, avelumab) show also next to promising results in cancer therapy a significant rate of cardiotoxic side effects. A list with selected substance classes and examples can be found in Table 1 .

Another prominent mode of cardiovascular damage associated with cancer therapy is radiation-induced CRC. It's noteworthy that radiation usually induces a spectrum of cardiomyopathies that differ from the chemotherapy-induced CRCs mentioned before. Frequent presentations are acute pericarditis, chronic pericarditis and myocardial fibrosis. These changes can occur with a delay up to 30 years after chest radiation (20). Improvements in involved-field radiation techniques and refined CT-based radiation planning reduced the incidence in recent years.

\section{Exercise training in cancer related cardiomyopathy}

If looking at effects of exercise training in CRC it is worth reviewing data from the general population first. Although it 
Table 1 List of selected substance classes and example substance with known cardiotoxicity

\begin{tabular}{|c|c|}
\hline Substance class & Substance \\
\hline \multirow[t]{4}{*}{ Anthracyclines } & Doxorubicin \\
\hline & Epirubicin \\
\hline & Idarubicin \\
\hline & Mitoxantrone \\
\hline \multirow[t]{4}{*}{ Alkylating agents } & Cyclophosphamide \\
\hline & Ifosfamide \\
\hline & Busulfan \\
\hline & Mitomycin \\
\hline \multirow[t]{4}{*}{ Antimetabolites } & Clofarabine \\
\hline & 5-fluorouracil \\
\hline & Capecitabine \\
\hline & Cytarabine \\
\hline Antimicrotubule agents & Vincristine \\
\hline \multirow{4}{*}{$\begin{array}{l}\text { Monoclonal antibody-based tyrosine } \\
\text { kinase inhibitors }\end{array}$} & Bevacizumab \\
\hline & Trastuzumab \\
\hline & Pertuzumab \\
\hline & Alemtuzumab \\
\hline \multirow{6}{*}{$\begin{array}{l}\text { Small-molecule tyrosine kinase } \\
\text { inhibitors }\end{array}$} & Dasatinib \\
\hline & Imatinib \\
\hline & Lapatinib \\
\hline & Sunitinib \\
\hline & Sorafenib \\
\hline & Pazopanib \\
\hline Proteasome inhibitor & Bortezomib \\
\hline
\end{tabular}

seems like an obvious truism that regular exercise is beneficial for healthy individuals and patients with cardiovascular diseases alike, there is objective data to support it. Regular physical activity does reduce the risk of cardiovascular morbidity and mortality (21). Furthermore, a fairly recent prospective cohort study enrolling 416,175 subjects showed a long-term benefit even for people who exercise moderately (approximately 90 minutes per week) compared to inactive individuals with a $14 \%$ reduced risk of all-cause mortality and a 3-year longer life expectancy. With increased activity, this effect could be improved even further (22).

When talking about systolic heart failure in general, exercise training has shown to be beneficial also in secondary prevention. The most notable and recent randomized trial was the HF-ACTION trial that enrolled 2,331 patients and randomized them to either standard medical care or standard care plus a supervised exercise regimen of 90 minutes per week. In the median follow up of about two and a half years, a non-significant reduction in mortality could be observed (23). Along these findings a Cochrane systematic review and meta-analysis published in 2016 also suggested a significant reduction in all-cause mortality and recurrent hospitalization for patients with exercised based structured rehabilitation compared to no-exercise controls (21). This data is reflected in a class I recommendation for patients with coronary heart disease and a class IIa recommendation for patients with chronic systolic heart failure in the current AHA/ACCF guidelines (24).

When looking at trials conducted during cancer treatment, the overwhelming majority of available evidence stems from trials conducted in woman with breast cancer. Since the therapy protocols frequently involve anthracyclines, cyclophosphamide and monoclonal antibody-based tyrosine kinase inhibitors as well as chest radiation this data might be specific for the distinct class of chemotherapeutic regimen and type of cancer.

\section{Exercise training before cancer therapy}

Preclinical trials conducted with mice showed a benefit for exercise training before initiating a potentially cardiotoxic therapy (25). This concept (also dubbed "pre-habilitation") seems intuitively appealing. By improving the functional cardiorespiratory capacity and activity levels beforehand, one might argue that the following functional decline might be alleviated or the development of heart failure even prevented altogether.

One trial published in 2014 evaluated a multimodal structured pre-habilitation protocol including moderate aerobic and resistance exercises, nutritional counseling with protein supplementation, and relaxation exercises. One group started the protocol 4 weeks before abdominal surgery for colorectal cancer while the other group started immediately after surgery. The authors showed a meaningful change in postoperative functional exercise capacity (26). However, to date there are no randomized trials evaluating a structured exercise regimen in the time period between diagnosis and the initiation of a specific systemic chemotherapy with respect to mortality or development of heart failure. 


\section{Exercise training during cancer therapy}

Even though many trials are comparatively small in their sample size most of them report a positive effect in peak oxygen uptake $\left(\mathrm{VO}_{2}\right.$ peak) as well as a reduction in fatigue and improvement in quality-of-life or other parameters of cardio-respiratory fitness. However, a notable issue besides the heterogeneity of the underlying disease is therapy adherence even in controlled study environments. Some trials report adherence rates as low as 59\%. A list of selected clinical trials during cancer therapy is listed in Table 2.

The general picture even though mostly supportive is not exclusively positive. One fairly recent randomized trial enrolled 101 participants and followed those patients for about one year. The authors could not report a significant improvement in physical functioning. However, this trial only included women with metastatic disease whereas the other trials could show the benefit for exercise therapy in patients with early-stage breast cancer (46). Additionally, no randomized controlled trials or phase III trials are available to address end-points beyond cardio-respiratory fitness. A single study reported next to an increase in $\mathrm{VO}_{2}$ peak an improvement in vascular endothelial function in the brachial artery (39). Furthermore even though there is no data that supports an actual harm of exercise therapy during ongoing cancer treatment, most trials do not systematically report safety endpoints.

\section{Exercise training after cancer therapy}

Evidence from phase III trials from exercise training during cancer therapy is not available yet. Observational studies however tend to show positive results for an active lifestyle. One trial published by Jones et al. in 2016 conducted a prospective cohort study that enrolled 2,973 women with non-metastatic breast cancer and followed them for a median of about 8.5 years. The authors could show an inverse relationship between exercise intensity and incidence of cardiovascular events in general and of coronary artery disease and heart failure in particular. In the multivariate analysis, the association did not differ according to age, CVD risk factors, menopausal status, or anticancer treatment (47). In young adults, this benefit might even be larger as reported in a trial enrolling 15,450 adult survivors of childhood cancer. This trial could report after a median follow-up of 10 years, comparing low physical activity (<3 MET-h.wk-1) and increased physical activity ( $\geq 3$ MET-h.wk-1), a reduction in all-cause (19\%), recurrence/progression (39\%) of the underlying malignant disease or and health-related deaths (11\%) (48).

Beyond observational data, most trials report end points limited to cardio-respiratory fitness. For example, a recent trial enrolled 152 breast cancer survivors participating in cardiac rehabilitation for 22 weeks. The authors could show improvements in health-related quality-of-life and depression as well as an improvement in $\mathrm{VO}_{2}$ peak by $14 \%$ (49).

Several trials report an improvement in cardio-respiratory fitness. For example, one trial published in 2017 showed among 63 survivors of testicular cancer that high-intensity aerobic interval training improved cardiovascular parameters such as arterial thickness, arterial stiffness, post-exercise parasympathetic reactivation, inflammation, and low-density lipoprotein when compared to usual care (50). A list of selected clinical trials during cancer therapy is listed in Table 3.

\section{Future studies}

As of today there are several trials recruiting that might further our understanding. For example, the Exercise to Prevent AnthraCycline-based Cardio-Toxicity Study 2.0 (EXACT 2, NCT03748550) aims to enroll 100 patients with breast cancer to be randomized either to standard care or aerobic exercise training. The primary outcome measure will be change in $L V$ function while change in cardiac biomarkers such as hs-TNT and N-terminal pro b-type natriuretic peptide are among the secondary endpoints. The trial is not expected to be completed until 2023.

Another study to look forward to regarding cardiovascular endpoints for patients undergoing cancer therapy is the Multidisciplinary Team IntervenTion in CArdio-Oncology trial (TITAN, NCT01621659). The authors aim to enroll nearly 300 participants with breast cancer or lymphoma and randomize to either standard care or to a multidisciplinary team-intervention consisting of cardiologists, clinical nutritionists, pharmacists, exercise physiologists and physiotherapists. Since the primary and secondary endpoints of this trial will be changes in longitudinal LV strain as well as heart failure associated biomarkers this trial might be able to identify subclinical changes in cardiac function. Furthermore smaller wearable activity monitors might help to improve the quality of the obtained data and possibly include more patients in future trials (56).

\section{Conclusions}

As of today there is only limited evidence that exercise 
Table 2 Selected trials investigating exercise intervention during active cancer treatment

\begin{tabular}{|c|c|c|c|c|}
\hline Study & Malignancy & $\mathrm{N}$ & Intervention & Outcome \\
\hline $\begin{array}{l}\text { MacVicar et al. } \\
\text { [1989] (27) }\end{array}$ & $\begin{array}{l}\text { Stage II breast } \\
\text { cancer }\end{array}$ & 45 & $\begin{array}{l}\text { Supervised aerobic exercise: } 60-85 \% \text { of maximum } \\
\text { heart rate for } 3 \text { days/week and } 10 \text { weeks }\end{array}$ & $\begin{array}{l}\text { Increase in } \mathrm{VO}_{2} \text { peak with aerobic } \\
\text { exercise }\end{array}$ \\
\hline $\begin{array}{l}\text { Kolden et al. } \\
\text { [2002] (29) }\end{array}$ & $\begin{array}{l}\text { Stage I-III breast } \\
\text { cancer }\end{array}$ & 40 & $\begin{array}{l}20 \text { minutes of aerobic exercise at } 70 \% \mathrm{VO}_{2} \max \text { for } \\
3 \text { days/week and } 16 \text { weeks }\end{array}$ & $\begin{array}{l}\text { Increase in } \mathrm{VO}_{2} \text { peak; reduction } \\
\text { in depression and systolic blood } \\
\text { pressure }\end{array}$ \\
\hline $\begin{array}{l}\text { Drouin et al. } \\
\text { [2006] (30) }\end{array}$ & $\begin{array}{l}\text { Stage 0-III breast } \\
\text { cancer }\end{array}$ & 20 & Supervised moderate aerobic exercise for 7 weeks & $\begin{array}{l}\text { Increase in } \mathrm{VO}_{2} \text { peak and red blood } \\
\text { cell count }\end{array}$ \\
\hline $\begin{array}{l}\text { Kim et al. } \\
\text { [2006] (31) }\end{array}$ & $\begin{array}{l}\text { Stage } 0-\text { III breast } \\
\text { cancer }\end{array}$ & 41 & $\begin{array}{l}30 \text { minutes supervised aerobic exercise at } 60-70 \% \\
\text { of } \mathrm{VO}_{2} \text { peak for } 3 \text { days/week and } 8 \text { weeks }\end{array}$ & $\begin{array}{l}\text { Increase in } \mathrm{VO}_{2} \text { peak; reduction } \\
\text { in resting heart rate and blood } \\
\text { pressure }\end{array}$ \\
\hline $\begin{array}{l}\text { Segal et al. } \\
\text { [2009] (34) }\end{array}$ & Prostate cancer & 121 & $\begin{array}{l}\text { Supervised aerobic exercise or resistance therapy for } \\
3 \text { days/weeks and } 24 \text { weeks }\end{array}$ & $\begin{array}{l}\text { Increase in } \mathrm{VO}_{2} \text { peak for resistance } \\
\text { therapy compared to usual care }\end{array}$ \\
\hline $\begin{array}{l}\text { Haykowsky } \\
\text { et al. [2009] (35) }\end{array}$ & $\begin{array}{l}\text { Stage I-Illa breast } \\
\text { cancer }\end{array}$ & 17 & $\begin{array}{l}\text { Supervised aerobic exercise at } 60-90 \% \text { of } \mathrm{VO}_{2} \text { peak, } \\
30-60 \mathrm{~min} / \text { day for } 3 \text { days/week and } 4 \text { months }\end{array}$ & $\begin{array}{l}\text { No change in } \mathrm{VO}_{2} \text { peak, blood } \\
\text { pressure, left ventricular ejection } \\
\text { fraction or left ventricular diameters }\end{array}$ \\
\hline $\begin{array}{l}\text { Ligibel et al. } \\
\text { [2010] (36) }\end{array}$ & $\begin{array}{l}\text { Stage I-III breast } \\
\text { cancer }\end{array}$ & 41 & $\begin{array}{l}\text { Moderate exercise at } 55-80 \% \text { of maximum heart rate } \\
\text { for } 120 \text { minutes/week and } 12 \text { weeks }\end{array}$ & $\begin{array}{l}\text { Increase in } \mathrm{VO}_{2} \text { peak and quality } \\
\text { of life }\end{array}$ \\
\hline $\begin{array}{l}\text { Noble et al. } \\
\text { [2012] (37) }\end{array}$ & $\begin{array}{l}\text { Breast cancer; } \\
\text { colorectal cancer; } \\
\text { hematological } \\
\text { malignancy }\end{array}$ & 386 & $\begin{array}{l}60 \text { minutes of aerobic exercise twice weekly for } \\
12 \text { weeks }\end{array}$ & $\begin{array}{l}\text { Decrease in systolic and diastolic } \\
\text { blood pressure }\end{array}$ \\
\hline $\begin{array}{l}\text { Jones et al. } \\
\text { [2013] (39) }\end{array}$ & Breast cancer & 20 & $\begin{array}{l}\text { Aerobic exercise at } 55-100 \% \mathrm{VO}_{2} \text { peak for } \\
3 \text { days/week and } 12 \text { weeks }\end{array}$ & $\begin{array}{l}\text { Increase in } \mathrm{VO}_{2} \text { peak and flow- } \\
\text { mediated dilation }\end{array}$ \\
\hline $\begin{array}{l}\text { Vincent et al. } \\
\text { [2013] (40) }\end{array}$ & $\begin{array}{l}\text { Stage I-III breast } \\
\text { cancer }\end{array}$ & 42 & $\begin{array}{l}\text { Home-based walking program at } 50-60 \% \text { of } \\
\text { maximum heart rate for } 3 \text { days/week and } 12 \text { weeks. }\end{array}$ & $\begin{array}{l}\text { Increase in } \mathrm{VO}_{2} \text { peak and 6-minute } \\
\text { walk test distance }\end{array}$ \\
\hline $\begin{array}{l}\text { Hornsby et al. } \\
{[2014](41)}\end{array}$ & $\begin{array}{l}\text { Stage IIb-IIIc } \\
\text { breast cancer }\end{array}$ & 20 & $\begin{array}{l}\text { Supervised aerobic exercise, } 15-45 \mathrm{~min} / \text { day at } \\
60-70 \% \text { of } \mathrm{VO}_{2} \text { peak for } 3 \text { days/week and } 12 \text { weeks }\end{array}$ & Increase in $\mathrm{VO}_{2}$ peak \\
\hline $\begin{array}{l}\text { Travier et al. } \\
\text { [2015] (42) }\end{array}$ & Breast cancer & 204 & $\begin{array}{l}\text { Supervised aerobic and strength exercise, } \\
60 \mathrm{~min} / \text { day for } 2 \text { days/week and } 18 \text { weeks }\end{array}$ & No significant difference in $\mathrm{VO}_{2}$ peak \\
\hline $\begin{array}{l}\text { Grabenbauer } \\
\text { et al. [2016] (43) }\end{array}$ & $\begin{array}{l}\text { Breast cancer; } \\
\text { gastrointestinal } \\
\text { cancer }\end{array}$ & 45 & $\begin{array}{l}\text { Supervised aerobic exercise, } 30-60 \mathrm{~min} / \text { day for } \\
3 \text { days/week for } 3-12 \text { months }\end{array}$ & $\begin{array}{l}\text { Increase in } \mathrm{VO}_{2} \text { peak in the first } \\
3 \text { months, after neither decline nor } \\
\text { increase }\end{array}$ \\
\hline $\begin{array}{l}\text { Cornette et al. } \\
\text { [2016] (44) }\end{array}$ & $\begin{array}{l}\text { Stage I-IIIB breast } \\
\text { cancer }\end{array}$ & 44 & $\begin{array}{l}\text { Home-based adapted physical activity program, } \\
20-40 \mathrm{~min} / \text { day for } 3 \text { days / week and } 27 \text { weeks }\end{array}$ & $\begin{array}{l}\text { Increase in } \mathrm{VO}_{2} \text { peak in the first } \\
3 \text { months, after neither decline nor } \\
\text { increase }\end{array}$ \\
\hline $\begin{array}{l}\text { Scott et al. } \\
{[2018](45)}\end{array}$ & $\begin{array}{l}\text { Breast cancer } \\
\text { with metastatic } \\
\text { disease }\end{array}$ & 65 & $\begin{array}{l}\text { Aerobic exercise at } 55-100 \% \mathrm{VO}_{2} \text { peak for } \\
3 \text { days/week and } 12 \text { weeks }\end{array}$ & No significant difference in $\mathrm{VO}_{2}$ peak \\
\hline
\end{tabular}


Table 3 Selected trials investigating exercise intervention after active cancer treatment

\begin{tabular}{|c|c|c|c|c|}
\hline Study & Malignancy & $\mathrm{N}$ & Intervention & Outcome \\
\hline $\begin{array}{l}\text { Pinto et al. } \\
\text { [2013] (52) }\end{array}$ & Colorectal cancer survivors & 46 & $\begin{array}{l}\text { Aerobic exercise, } 10-30 \text { minutes } \\
\text { for 2-5 days/week and } 48 \text { weeks }\end{array}$ & Increase in $\mathrm{VO}_{2}$ peak \\
\hline $\begin{array}{l}\text { Jones et al. } \\
\text { [2014] (53) }\end{array}$ & $\begin{array}{l}\text { Cancer survivors with signs of } \\
\text { heart failure after therapy }\end{array}$ & 90 & $\begin{array}{l}\text { Aerobic exercise, } 20-45 \text { minutes } \\
\text { for } 4 \text { days/week and } 52 \text { weeks }\end{array}$ & $\begin{array}{l}\text { No difference inVO }{ }_{2} \text { peak between } \\
\text { aerobic exercise and usual care }\end{array}$ \\
\hline $\begin{array}{l}\text { Jones et al. } \\
\text { [2014] (54) }\end{array}$ & $\begin{array}{l}\text { Prostate cancer } 75 \mathrm{~d} \text { after } \\
\text { therapy }\end{array}$ & 50 & $\begin{array}{l}\text { Aerobic exercise, } 30-45 \text { minutes } \\
\text { for } 2-5 \text { days/week and } 48 \text { weeks }\end{array}$ & $\begin{array}{l}\text { Increase in } \mathrm{VO}_{2} \text { peak and flow-mediated } \\
\text { dilation }\end{array}$ \\
\hline $\begin{array}{l}\text { Rogers et al. } \\
\text { [2015] (55) }\end{array}$ & Breast cancer survivors & 222 & $\begin{array}{l}\text { Aerobic exercise, } 15-50 \text { minutes } \\
\text { for } 3-5 \text { days/week and } 12 \text { weeks }\end{array}$ & $\begin{array}{l}\text { No difference inVO }{ }_{2} \text { peak between } \\
\text { Aerobic exercise and usual care }\end{array}$ \\
\hline
\end{tabular}

therapy can actually prevent or mitigate CRC. However, there is plenty of evidence to support the importance of exercise in cancer treatments in order to improve cardiorespiratory fitness of patients during and after cancer treatment. This significantly improves typical treatment associated symptoms such as fatigue which is an important end-point for patients and physicians alike. However, it cannot be a suitable surrogate parameter for actually improving cardiac function or decreasing cardiovascular mortality.

As the number of patients with malignancy and the number of patients surviving cancer treatment is expected to rise, large and randomized prospective trials will be needed to evaluate the safety, intensity and efficacy of exercise training in the different stages of cancer treatment. More importantly cardiovascular endpoints such as re-hospitalization due to heart failure, death due to cardiovascular causes or echocardiographic parameters defining the ventricular function need to be reported in order to better attribute any effect to an improvement of CRC.

The need of an interdisciplinary approach for patients as complex as cancer patients with an ever increasing number of available substances, improving survival rates and. Therefore, the field of onco-cardiology will become more and more important in an aging population with a rising prevalence of multimorbidity.

\section{Acknowledgements}

None.

\section{Footnote}

Conflicts of Interest: The authors have no conflicts of interest to declare.

\section{References}

1. Miller KD, Siegel RL, Lin CC, et al. Cancer treatment and survivorship statistics, 2016. CA Cancer J Clin 2016;66:271-89.

2. Payne DL, Nohria A. Prevention of Chemotherapy Induced Cardiomyopathy. Curr Heart Fail Rep 2017;14:398-403.

3. Higgins AY, O'Halloran TD, Chang JD. Chemotherapyinduced cardiomyopathy. Heart Fail Rev 2015;20:721-30.

4. Koene RJ, Prizment AE, Blaes A, et al. Shared Risk Factors in Cardiovascular Disease and Cancer. Circulation 2016;133:1104-14.

5. Rasmussen-Torvik LJ, Shay CM, Abramson JG, et al. Ideal cardiovascular health is inversely associated with incident cancer: the Atherosclerosis Risk In Communities study. Circulation 2013;127:1270-5.

6. Patnaik JL, Byers T, DiGuiseppi C, et al. Cardiovascular disease competes with breast cancer as the leading cause of death for older females diagnosed with breast cancer: a retrospective cohort study. Breast Cancer Res 2011;13:R64.

7. Wang F, Gulati R, Lennon RJ, et al. Cancer History Portends Worse Acute and Long-term Noncardiac (but Not Cardiac) Mortality After Primary Percutaneous 
Coronary Intervention for Acute ST-Segment Elevation Myocardial Infarction. Mayo Clin Proc 2016;91:1680-92.

8. Khan NF, Mant D, Carpenter L, et al. Long-term health outcomes in a British cohort of breast, colorectal and prostate cancer survivors: a database study. Br J Cancer 2011;105 Suppl 1:S29-37.

9. Plana JC, Galderisi M, Barac A, et al. Expert consensus for multimodality imaging evaluation of adult patients during and after cancer therapy: a report from the American Society of Echocardiography and the European Association of Cardiovascular Imaging. Eur Heart J Cardiovasc Imaging 2014;15:1063-93.

10. Blanchard CM, Courneya KS, Stein K, et al. Cancer survivors' adherence to lifestyle behavior recommendations and associations with health-related quality of life: results from the American Cancer Society's SCS-II. J Clin Oncol 2008;26:2198-204.

11. Herrmann J, Lerman A, Sandhu NP, et al. Evaluation and management of patients with heart disease and cancer: cardio-oncology. Mayo Clin Proc 2014;89:1287-306.

12. Ewer MS, Lippman SM. Type II chemotherapy-related cardiac dysfunction: time to recognize a new entity. J Clin Oncol 2005;23:2900-2.

13. Cardinale D, Colombo A, Lamantia G, et al. Anthracycline-induced cardiomyopathy: clinical relevance and response to pharmacologic therapy. J Am Coll Cardiol 2010;55:213-20.

14. Fallah-Rad N, Lytwyn M, Fang T, et al. Delayed contrast enhancement cardiac magnetic resonance imaging in trastuzumab induced cardiomyopathy. J Cardiovasc Magn Reson 2008;10:5.

15. Seidman A, Hudis C, Pierri MK, et al. Cardiac dysfunction in the trastuzumab clinical trials experience. J Clin Oncol 2002;20:1215-21.

16. Stewart S, MacIntyre K, Hole DJ, et al. More 'malignant' than cancer? Five-year survival following a first admission for heart failure. Eur J Heart Fail 2001;3:315-22.

17. Felker GM, Thompson RE, Hare JM, et al. Underlying causes and long-term survival in patients with initially unexplained cardiomyopathy. N Engl J Med 2000;342:1077-84.

18. Yeh ET, Bickford CL. Cardiovascular complications of cancer therapy: incidence, pathogenesis, diagnosis, and management. J Am Coll Cardiol 2009;53:2231-47.

19. Ewer MS, Ewer SM. Cardiotoxicity of anticancer treatments: what the cardiologist needs to know. Nat Rev Cardiol 2010;7:564-75.

20. Jaworski C, Mariani JA, Wheeler G, et al. Cardiac complications of thoracic irradiation. J Am Coll Cardiol 2013;61:2319-28.

21. Anderson L, Oldridge N, Thompson DR, et al. ExerciseBased Cardiac Rehabilitation for Coronary Heart Disease: Cochrane Systematic Review and Meta-Analysis. J Am Coll Cardiol 2016;67:1-12.

22. Wen CP, Wai JP, Tsai MK, et al. Minimum amount of physical activity for reduced mortality and extended life expectancy: a prospective cohort study. Lancet 2011;378:1244-53.

23. Flynn KE, Pina IL, Whellan DJ, et al. Effects of exercise training on health status in patients with chronic heart failure: HF-ACTION randomized controlled trial. JAMA 2009;301:1451-9.

24. Smith SC Jr, Benjamin EJ, Bonow RO, et al. AHA/ACCF secondary prevention and risk reduction therapy for patients with coronary and other atherosclerotic vascular disease: 2011 update: a guideline from the American Heart Association and American College of Cardiology Foundation endorsed by the World Heart Federation and the Preventive Cardiovascular Nurses Association. J Am Coll Cardiol 2011;58:2432-46.

25. Marques-Aleixo I, Santos-Alves E, Mariani D, et al. Physical exercise prior and during treatment reduces subchronic doxorubicin-induced mitochondrial toxicity and oxidative stress. Mitochondrion 2015;20:22-33.

26. Gillis C, Li C, Lee L, et al. Prehabilitation versus rehabilitation: a randomized control trial in patients undergoing colorectal resection for cancer. Anesthesiology 2014;121:937-47.

27. MacVicar MG, Winningham ML, Nickel JL. Effects of aerobic interval training on cancer patients' functional capacity. Nurs Res 1989;38:348-51.

28. Segal R, Evans W, Johnson D, et al. Structured exercise improves physical functioning in women with stages I and II breast cancer: results of a randomized controlled trial. J Clin Oncol 2001;19:657-65.

29. Kolden GG, Strauman TJ, Ward A, et al. A pilot study of group exercise training (GET) for women with primary breast cancer: feasibility and health benefits. Psychooncology 2002;11:447-56.

30. Drouin JS, Young TJ, Beeler J, et al. Random control clinical trial on the effects of aerobic exercise training on erythrocyte levels during radiation treatment for breast cancer. Cancer 2006;107:2490-5.

31. Kim CJ, Kang DH, Smith BA, et al. Cardiopulmonary responses and adherence to exercise in women newly diagnosed with breast cancer undergoing adjuvant therapy. 
Cancer Nurs 2006;29:156-65.

32. Courneya KS, Segal RJ, Mackey JR, et al. Effects of aerobic and resistance exercise in breast cancer patients receiving adjuvant chemotherapy: a multicenter randomized controlled trial. J Clin Oncol 2007;25:4396-404.

33. Courneya KS, Sellar CM, Stevinson C, et al. Randomized controlled trial of the effects of aerobic exercise on physical functioning and quality of life in lymphoma patients. J Clin Oncol 2009;27:4605-12.

34. Segal RJ, Reid RD, Courneya KS, et al. Randomized controlled trial of resistance or aerobic exercise in men receiving radiation therapy for prostate cancer. J Clin Oncol 2009;27:344-51.

35. Haykowsky MJ, Mackey JR, Thompson RB, et al. Adjuvant trastuzumab induces ventricular remodeling despite aerobic exercise training. Clin Cancer Res 2009;15:4963-7.

36. Ligibel JA, Partridge A, Giobbie-Hurder A, et al. Physical and psychological outcomes among women in a telephonebased exercise intervention during adjuvant therapy for early stage breast cancer. J Womens Health (Larchmt) 2010;19:1553-9.

37. Noble M, Russell C, Kraemer L, et al. UW WELL-FIT: the impact of supervised exercise programs on physical capacity and quality of life in individuals receiving treatment for cancer. Support Care Cancer 2012;20:865-73.

38. Courneya KS, McKenzie DC, Mackey JR, et al. Effects of exercise dose and type during breast cancer chemotherapy: multicenter randomized trial. J Natl Cancer Inst 2013;105:1821-32.

39. Jones LW, Fels DR, West M, et al. Modulation of circulating angiogenic factors and tumor biology by aerobic training in breast cancer patients receiving neoadjuvant chemotherapy. Cancer Prev Res (Phila) 2013;6:925-37.

40. Vincent F, Labourey JL, Leobon S, et al. Effects of a home-based walking training program on cardiorespiratory fitness in breast cancer patients receiving adjuvant chemotherapy: a pilot study. Eur J Phys Rehabil Med 2013;49:319-29.

41. Hornsby WE, Douglas PS, West MJ, et al. Safety and efficacy of aerobic training in operable breast cancer patients receiving neoadjuvant chemotherapy: a phase II randomized trial. Acta Oncol 2014;53:65-74.

42. Travier N, Velthuis MJ, Steins Bisschop CN, et al. Effects of an 18-week exercise programme started early during breast cancer treatment: a randomised controlled trial. BMC Med 2015;13:121.

43. Grabenbauer A, Grabenbauer AJ, Lengenfelder R, et al.
Feasibility of a 12-month-exercise intervention during and after radiation and chemotherapy in cancer patients: impact on quality of life, peak oxygen consumption, and body composition. Radiat Oncol 2016;11:42.

44. Cornette T, Vincent F, Mandigout S, et al. Effects of home-based exercise training on $\mathrm{VO} 2$ in breast cancer patients under adjuvant or neoadjuvant chemotherapy (SAPA): a randomized controlled trial. Eur J Phys Rehabil Med 2016;52:223-32.

45. Scott JM, Iyengar NM, Nilsen TS, et al. Feasibility, safety, and efficacy of aerobic training in pretreated patients with metastatic breast cancer: A randomized controlled trial. Cancer 2018;124:2552-60.

46. Ligibel JA, Giobbie-Hurder A, Shockro L, et al. Randomized trial of a physical activity intervention in women with metastatic breast cancer. Cancer 2016;122:1169-77.

47. Jones LW, Habel LA, Weltzien E, et al. Exercise and Risk of Cardiovascular Events in Women With Nonmetastatic Breast Cancer. J Clin Oncol 2016;34:2743-9.

48. van Waart H, Stuiver MM, van Harten WH, et al. Effect of Low-Intensity Physical Activity and Moderateto High-Intensity Physical Exercise During Adjuvant Chemotherapy on Physical Fitness, Fatigue, and Chemotherapy Completion Rates: Results of the PACES Randomized Clinical Trial. J Clin Oncol 2015;33:1918-27.

49. Dolan LB, Barry D, Petrella T, et al. The Cardiac Rehabilitation Model Improves Fitness, Quality of Life, and Depression in Breast Cancer Survivors. J Cardiopulm Rehabil Prev 2018;38:246-52.

50. Adams SC, DeLorey DS, Davenport MH, et al. Effects of high-intensity aerobic interval training on cardiovascular disease risk in testicular cancer survivors: A phase 2 randomized controlled trial. Cancer 2017;123:4057-65.

51. Courneya KS, Mackey JR, Bell GJ, et al. Randomized controlled trial of exercise training in postmenopausal breast cancer survivors: cardiopulmonary and quality of life outcomes. J Clin Oncol 2003;21:1660-8.

52. Pinto BM, Papandonatos GD, Goldstein MG, et al. Home-based physical activity intervention for colorectal cancer survivors. Psychooncology 2013;22:54-64.

53. Jones LW, Douglas PS, Khouri MG, et al. Safety and efficacy of aerobic training in patients with cancer who have heart failure: an analysis of the HF-ACTION randomized trial. J Clin Oncol 2014;32:2496-502.

54. Jones LW, Hornsby WE, Freedland SJ, et al. Effects of nonlinear aerobic training on erectile dysfunction and cardiovascular function following radical prostatectomy for 
clinically localized prostate cancer. Eur Urol 2014;65:852-5.

55. Rogers LQ, Courneya KS, Anton PM, et al. Effects of the BEAT Cancer physical activity behavior change intervention on physical activity, aerobic fitness, and quality of life in breast cancer survivors: a multicenter randomized controlled trial. Breast Cancer Res Treat 2015;149:109-19.

56. Gresham G, Schrack J, Gresham LM, et al. Wearable activity monitors in oncology trials: Current use of an emerging technology. Contemp Clin Trials 2018;64:13-21.
Cite this article as: Westphal JG, Schulze PC. Exercise training in cancer related cardiomyopathy. J Thorac Dis 2018;10(Suppl 35):S4391-S4399. doi: 10.21037/jtd.2018.12.53 